\title{
PENGARUH FAKTOR INTERNAL DAN EKSTERNAL BANK SYARIAH TERHADAP KEPUTUSAN INVESTASI
} SURAT BERHARGA BANK SYARIAH ${ }^{1}$

\author{
Izzadin Nur Muhammad \\ Departemen Ekonomi Syariah-Fakultas Ekonomi dan Bisnis-Universitas Airlangga \\ Email: izzadin.nur.muhammad-2014@feb.unair.ac.id
}

\section{Noven Suprayogi}

Departemen Ekonomi Syariah-Fakultas Ekonomi dan Bisnis-Universitas Airlangga

Email: noven.suprayogi@feb.unair.ac.id

\begin{abstract}
:
Investments of securities performed by Islamic banks in addition to a liquidity instrument in the bank that is as an investment instrument for banks to obtain operating income other than the channeling of funds through financing to customers. The Bank's securities investment is influenced by external and internal factors within the bank. External factors are factors that occur outside the bank, external factors can not be controlled by the management of sharia banks. Internal factors are factors that occur due to decisions and phenomena within the internal bank, internal factors can be controlled by banks through managerial processes. External factors faced by banks such as economic and monetary conditions such as inflation and interest rates, money market conditions (exchange rate), customer character, regulations and others. Internal factors rely heavily on bank management in managing every liquid instrument within the sharia bank itself, such as asset and liability management.
\end{abstract}

Keywords: Sharia Bank, Investment, SBSN, Liquid Instruments

\section{PENDAHULUAN}

Perbankan telah dikenal sejak zaman Babylonia, Yunani dan Romawi, walaupun pada zaman tersebut hanya sebatas pada tukar-menukar uang. Transaksi yang dapat dilakukan di bank semakin lama semakin kompleks seperti yang terjadi dalam dunia perbankan modern saat ini. Dari yang kegiatan yang terbatas pada tukar-menukar uang, kini perbankan telah bertumbuh dan menjadi salah satu penyokong perekonomian dalam suatu negara yang menyediakan berbagai jenis produk. Fungsi utama perbankan, terutama bank konvesional pada umumnya saat ini adalah sebagai lembaga intermediary atau perantara dengan cara mengumpulkan pendanaan dari pihak yang surplus yang akan dipinjamkan ke pihak yang defisit dengan memungut bunga pada setiap peminjam yang harus dibayar.

Allah SWT sangat melarang seseorang memungut tambahan dalam sebuah transaksi pinjam-meminjam dalam Surat Al-Baqarah 275 yang bunyinya:

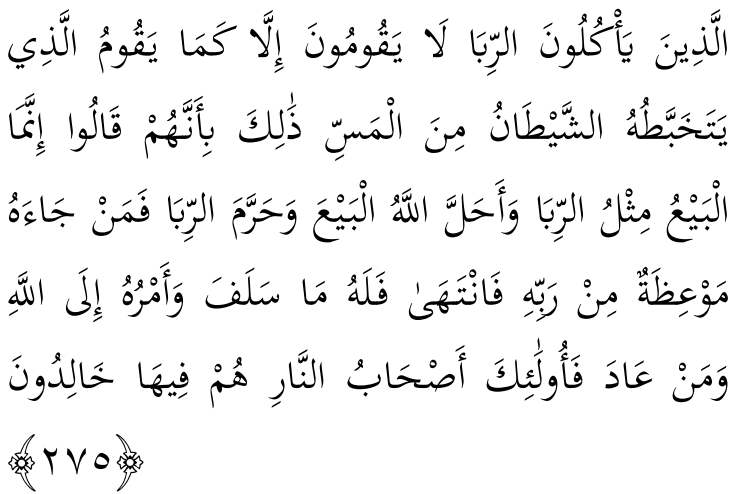

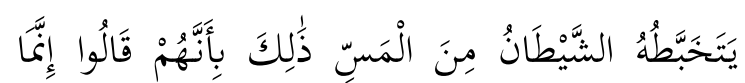

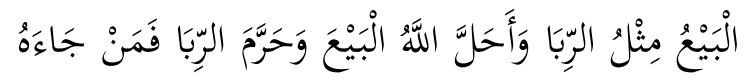

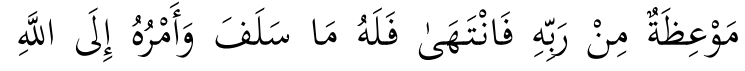

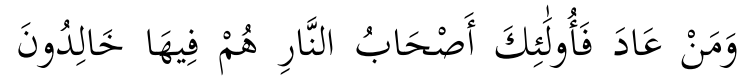
TVO

\footnotetext{
${ }^{1}$ Jurnal ini merupakan bagian dari skripsi Izzadin Nur Muhammad, NIM: 041411431029, yang diuji pada tanggal 17 April 2018.
} 
Muhammad, et al/Jurnal Ekonomi Syariah Teori dan Terapan Vol. 6 No. 4 April 2019: 672-686; PENGARUH FAKTOR INTERNAL DAN EKSTERNAL BANK SYARIAH TERHADAP KEPUTUSAN INVESTASI SURAT BERHARGA BANK SYARIAH

Artinya: Orang-orang yang memakan riba tidak dapat berdiri melainkan seperti berdirinya orang yang kemasukan setan karena gila. Yang demikian itu karena mereka berkata bahwa jual beli sama dengan riba. Padahal Allah telah menghalalkan jual beli dan mengharamkan riba. Barangsiapa mendapat peringatan dari Tuhannya, lalu dia berhenti, maka apa yang telah diperolehnya dahulu menjadi miliknya dan urusannya (terserah) kepada Allah. Barangsiapa mengulangi, maka mereka itu penghuni neraka, mereka kekal di dalamnya.

Dana pihak ketiga selain dapat dipergunakan untuk pembiayaan kepada nasabah juga bisa dipergunakan untuk kegiatan produktif lainnya seperti investasi surat berharga. Investasi surat berharga dalam perbankan syariah salah satunya bertujuan untuk menjaga likuiditas seperti yang diungkapkan oleh Anspachs et al (2015) dalam Muljawan dkk (2014:1) bahwa untuk langkah yang dapat dilakukan oleh perbankan syariah dalam mengantisipasi terjadinya kekurangan likuiditas yang berbahaya bagi keberlangsungan hidup bank, maka bank dapat melakukan tiga upaya yang salah satunya adalah memegang likuiditas cadangan disisi aktiva (seperti kas, penempatan pada bank sentral atau bank lainnya, dan surat-surat berharga baik yang diterbitkan oleh pemerintah maupun korporasi) untuk menekan probability of liquidity.
Investasi surat berharga yang dilakukan oleh bank syariah selain menjadi instrumen likuiditas pada bank yaitu sebagai instrumen investasi bagi bank untuk mendapatkan pendapatan operasional selain dari penyaluran dana melalui pembiayaan ke nasabah. Bank akan mendapatkan keuntungan dari imbal hasil atau return yang dapat dimanfaatkan untuk membayar dan memenuhi kewajiban-kewajiban maupun untuk pengembangan usahanya. Pendapatan dari investasi surat berharga merupakan salah satu komponen pendapatan yang dibagihasilkan kepada nasabah. Dari latar belakang tersebut sehingga muncul perumusan masalah diajukan dalam pertanyaan sebagai berikut:

a. Apakah Financing to Deposit Ratio (FDR), Penempatan pada Bank Indonesia, dan Inflasi berpengaruh secara parsial pada keputusan Investasi Surat Berharga Bank Umum Syariah di Indonesia?

b. Apakah Financing to Deposit Ratio (FDR), Penempatan pada Bank Indonesia, dan Inflasi berpengaruh secara simultan pada keputusan Investasi Surat Berharga Bank Umum Syariah di Indonesia?

\section{LANDASAN TEORI}

Sesuai dengan UU No. 21 Tahun 2008, bank syariah adalah sebuah bank yang melakukan kegiatan usaha berlandaskan dengan prinsip syariah yang kemudian dibagi berdasarkan jenisnya 
yaitu Bank Umum Syariah dan Bank Pembiayaan Rakyat Syariah. (Soemitra, 2009:61). Bank syariah merupakan lembaga keuangan yang berjalan dan mengembangkan produk-produk keuangan yang berdasarkan pada AlQur'an dan Al-Hadits. Core business yang dilakukan oleh bank syariah adalah menyalurkan pembiayaan kepada nasabah dan menyediakan jasa kevangan lainnya dalam peredaran vang sesuai dengan prinsip-prinsip syariah Islam (Muhammad, 2005:13).

Prinsip fundamental dari sebuah bank syariah adalah syariat Islam yang tertuang dalam Al- Qur'an dan Al-Hadits. Bank syariah dilarang melakukan transaksi yang tidak diperbolehkan dalam hukum Islam yaitu transaksi yang mengandung riba, ketidak jelasan (gharar), judi (maysir), penipuan/fraud (tadlis), dan transaksi atas barang-barang yang diharamkan oleh Allah dan Rasulnya. Bank syariah hanya boleh melakukan transaksi yang sesuai dengan Al-Qur'an dan Al-Hadits.

Manajemen dana Bank Syariah menurut Muhammad (2002) adalah pengelolaan posisi dana oleh bank syariah yang dikumpulkan oleh bank dari aktivitas pendanaan (funding) yang akan digunakan untuk kepada aktivitas pembiayaan (financing), dengan tujuan bank yang bersangkutan tetap mampu memenuhi kriteria rasio - rasio likuiditas, rentabilitas dan solvabilitas yang telah ditetapkan oleh otoritas keuangan.
Manajemen dana bank syariah bertujuan sebagai berikut (Ascarya ,2008: 112):

a. Memperoleh profit yang optimal.

b. Menyediakan aktiva cair dan kas yang memadai.

c. Penyimpan cadangan.

d. Mengelola kegiatan-kegiatan lembaga ekonomi dengan kebijakan yang pantas bagi seseorang yang bertindak sebagai pemelihara dana-dana orang lain.

e. Memenuhi kebutuhan masyarakat akan pembiayaan.

Manajemen Likuiditas bank syariah adalah merencanakan dan mengelola agar bank syariah dapat memenuhi baik liabilitas segera maupun liabilitas yang akan datang bila terjadi penarikan atau pelunasan asset liability yang sesuai perjanjian ataupun yang belum diperjanjikan (Ichsan,2013:108). Manajemen likuiditas bank syariah yang baik dan profesional dapat memberikan keyakinan pada para nasabah pendanaan bahwa mereka dapat mengambil dananya sewaktu-waktu atau pada saat jatuh tempo. Menurut Muhammad (2004) dalam Ichsan (2013:108), suatu bank syari'ah dikatakan likuid apabila :

a. Dapat memelihara Giro Wajib Minimum (GWM) di Bank Indonesia sesuai dengan yang telah ditentukan oleh Bank Indonesia.

b. Dapat memelihara Giro di Bank Koresponden. Giro di Bank 
Muhammad, et al/Jurnal Ekonomi Syariah Teori dan Terapan Vol. 6 No. 4 April 2019: 672-686; PENGARUH FAKTOR INTERNAL DAN EKSTERNAL BANK SYARIAH TERHADAP KEPUTUSAN INVESTASI SURAT BERHARGA BANK SYARIAH

Koresponden adalah rekening yang dipelihara di Bank Koresponden yang besarannya telah ditetapkan berdasarkan ketentuan Saldo Minimum yang berlaku.

c. Dapat memelihara sejumlah kas secukupnya untuk memenuhi pengambilan uang tunai.

Dalam pengelolaan dana, bank akan mengalami satu dari tiga hal di bawah ini :

a. Posisi seimbang (square) adalah dimana persedian dana bank syariah sama dengan kebutuhan dana yang tersedia.

b. Posisi lebih (long) adalah dimana persediaan dana bank syariah lebih dari kebutuhan dana yang tersedia.

c. Posisi kurang (short) adalah dimana persediaan dana bank syariah sedang kekurangan dana.

Dengan melakukan manajemen likuiditas maka Bank akan dapat memelihara likuiditas yang dianggap sehat dengan ciri-ciri sebagai berikut (Ichsan,2013:112) :

a. Memiliki sejumlah alat likuid, cash asset (vang kas, rekening pada bank sentral dan bank lainnya) setara dengan kebutuhan likuiditas yang diperkirakan,

b. Memiliki likuiditas kurang dari kebutuhan, tetapi memiliki surat-surat berharga yang segera dapat dialihkan menjadi kas, tanpa harus mengalami kerugian baik sebelum atau sesudah jatuh tempo,

c. Memiliki kemampuan untuk memperoleh likuiditas dengan cara menciptakan vang, misalnya dengan menjual surat berharga dengan repurchase agreement.

d. Memenuhi ratio pengukuran likuiditas yang sehat, salah satunya adalah rasio financing to deposit ratio. Rasio ini harus dipelihara pada posisi tertentu yaitu $75-100 \%$. Jika rasio FDR di bawah $75 \%$ maka bank sedang dalam kondisi over-liquidity, dan jika rasio FDR diatas 100\% maka bank dalam kondisi kurang likuid. Menurut kriteria Bank Indonesia, ketika rasio FDR perbankan melebihi $115 \%$ maka nilai kesehatan likuiditas bank adalah nol.

Manajemen likuiditas di bank syariah menurut Muhamad (2015:173) merupakan bagian dari asset dan liability management yang secara umum bertujuan untuk menjaga likuiditas suatu bank syariah agar kegiatan operasional bank tetap berlangsung, dan kepercayaan masyarakat tetap terjaga. Menurut Moestadjab (1995: 47-48), ketika bank dalam kondisi high liquidity atau over likuid, maka manajemen bank dapat menerapkan beberapa strategi sebagai berikut:

a. Spreading Maturity (Penyebaran Jangka Waktu)

Strategi penyebaran jangka waktu (Spreading Maturity)adalah strategi diversifikasi waktu jatuh tempo dari pendanaan bank seperti, deposito dan/atau sertifikat deposito dalam waktu jatuh tempo yang berbedabeda atau seimbangnya jumlah 
deposito yang berjangka waktu 1 bulan, 3 bulan, 6 bulan, dan 1 tahun. Penyebaran jangka waktu sumber dana diusahakan seimbang dengan kredit yang diberikan, agar tidak terjadi gap atau mis-match. Apabila sumber dana didominasi oleh sumber dana jangka pendek ( $<1$ tahun) sedangkan kredit yang diberikan oleh bank lebih banyak yang berjangka sangat pendek ( 3 bulan), maka bank akan terdapat banyak dana yang lebih atau idle fund, berlaku pula sebaliknya.

b. Spreading Loan (Penyebaran Kredit) Strategi penyebaran kredit bertujuan agar kredit yang diberikan oleh bank tidak hanya terkonsentrasi pada suatu nasabah tertentu dalam jumlah yang besar, maka dalam pemberian kredit harus ada keseimbangan kepada nasabah menengah ke bawah. Sebab apabila sebagian kredit hanya terkonsentrasi pada beberapa nasabah saja maka akan berdampak terhadap likuiditas bank.

c. Placement Strategy

Strategi ini menekankan bahwa porsi kredit atau pembiayaan dalam perbankan mengambil porsi terbesar dalam penempatan dana bank, sedangkan penempatan dana pada secondary reserve dan primary reserve (reserve requirement) hanya sebatas ketentuan yang berlaku. Bila terdapat kesulitan dalam penempatan dana berupa kredit atau pembiayaan, maka penempatan dana pada secondary reserve harus benar-benar diperhatikan dan menguntungkan.

d. Monitoring Cash Flow

Strategi monitoring arus kas dapat dilakukan dengan langkah pencegahan (preventif) dimana bank harus melakukan dengan cara memantau arus kas secara cermat dan teliti setiap harinya, sehingga probabilitas terjadinya over liquid atau under liquid dapat diantisipasi lebih awal.

e. Spreading Fund

Strategi ini menekankan agar sumber dana yang dihimpun oleh bank sebaiknya tidak terkonsentrasi pada beberapa nasabah saja namun harus tersebar kepada banyak nasabah, agar likuiditas dapat dipertahankan dengan stabil.

Bank syariah adalah intermediasi keuangan yang menjalankan aktifitas sesuai dengan syariat islam. Karena itu bank membutuhkan dana agar fungsi intermediasinya tetap terjaga, berikut kegiatan penghimpunan dana bank syariah menurut Soemitra (2009:73) agar bank tetap dapat menjalankan fungsinya:

1. Modal inti (core capital)

Soemitra (2009:73) menyebutkan modal inti merupakan dana modal sendiri yaitu dana yang berasal dari para pemegang saham bank, yakni pemilik bank. Modal inti terdiri dari 3 , yaitu :

a. Modal yang disetor oleh pemegang saham. Sumber dana ini hanya 
timbul apabila pemilik menyertakan dananya pada bank melalui pembelian saham. Setiap akhir tahun seluruh pemegang saham berhak mendapatkan bagi hasil keuntungan berupa dividen.

b. Cadangan-cadangan, yaitu sebagian laba yang tidak dibagi, disisihkan untuk menutup timbulnya risiko kerugian di kemudian hari.

c. Laba ditahan, yaitu sebagian laba yang seharusnya dibagikan kepada pemegang saham, tetapi para pemegang saham sepakat melalui RUPS untuk menahan sebagian atau seluruh laba untuk ditanam kembali sebagai modal.

\section{Dana Pihak Ketiga}

Sumber dana terbesar yang paling diandalkan bank yaitu dana simpanan dari nasabah. Porsi Dana Pihak Ketiga mencapai lebih dari $80 \%$ dana bank syariah. Dana Pihak Ketiga (DPK) terdiri dari 2 jenis, yaitu simpanan dan investasi. Simpanan yang dihimpun oleh bank syariah berdasarkan dengan akad wadi'ah atau akad lain yang tidak bertentangan dengan syariah dapat berbentuk giro, tabungan, atau produk lain yang dipersamakan. Sedangkan investasi dalah dana yang dipercayakan nasabah untuk dikelola oleh bank syariah sesuai dengan akad mudharabah atau akad lain yang tidak bertentangan dengan hukum islam.

Dana Pihak Ketiga (DPK) yang telah dikumpulkan oleh bank, maka bank berkewajiban agar dana tersebut tidak mengendap dan disalurkan untuk pembiayaan sesuai dengan fungsi bank sebagai lembaga intermediary. Menurut Arifin (2009:63) bank harus mempersiapkan strategi penggunaan dana-dana yang dihimpunnya sesuai dengan rencana alokasi berdasarkan kebijakan yang telah digariskan. Alokasi dana ini mempunyai beberapa tujuan yaitu:

1. Mencapai tingkat profitabilitas yang cukup dan tingkat risiko yang rendah.

2. Mempertahankan kepercayaan masyarakat dengan menjaga agar posisi likuiditas tetap aman.

Arifin (2009:63-64) menyebutkan alokasi penggunaan dana bank syariah pada dasarnya dapat dibagi dalam dua bagian penting dari aktiva bank, yaitu :

1. Earning Assests (aktiva yang menghasilkan)

Asset bank yang digunakan untuk menghasilkan pendapatan. Asset ini disalurkan dalam bentuk investasi yang terdiri dari Pembiayaan berdasarkan prinsip bagi hasil (Mudharabah), Pembiayaan berdasarkan prinsip penyertaan (Musyarakah), Pembiayaan berdasarkan prinsip jual beli (Al Bai'i), Pembiayaan berdasarkan prinsip sewa (ljarah, ljarah latina, \& IMBT), dan Surat-surat berharga Syariah dan investasi lainnya.

2. Non Earning Assets (aktiva yang tidak menghasilkan) 
Aktiva ini dapat dibagi sebagai berikut (Arifin, 2003:53-59):

a. Alat-alat likuid.

Alat likuid atau cash asset adalah aset bank yang dapat digunakan setiap saat untuk memenuhi kebutuhan likuiditas bank. Aktiva ini merupakan aktiva yang paling likuid dari keseluruhan aktiva bank. Komponen alat likuid menurut ketentuan Bank Indonesia terdiri dari vang kas yang ada pada bank dan saldo rekening giro pada Bank Indonesia.

b. Aktiva tetap dan inventaris.

Aktiva tetap yang dimiliki bank dapat berbentuk tanah, gedung kantor (baik kantor pusat maupun cabang-cabang), peralatan kantor seperti komputer, ATM, peralatan promosi, dan lain-lain.

Financing to Deposit Ratio (FDR) merupakan rasio yang menyatakan seberapa jauh kemampuan bank dalam membayar kembali penarikan dana yang dilakukan dengan mengandalkan dana pihak ketiga yang diberikan sebagai sumber. Kasmir (2012:331) juga menyatakan Financing to Deposit Ratio (FDR) adalah rasio yang digunakan untuk mengukur komposisi jumlah kredit yang diberikan dibandingkan dengan jumlah dana masyarakat dan modal sendiri yang digunakan. Rasio yang tinggi menunjukkan bahwa bank meminjamkan seluruh dananya atau relatif tidak likuid. Sebaliknya rasio yang rendah menunjukkan bank yang likuid dengan kelebihan kapasitas dana yang siap untuk dibiayai kepada nasabah. Oleh karena itu, rasio ini juga dapat untuk memberi isyarat apakah suatu pembiayaan masih dapat mengalami ekspansi atau sebaliknya dibatasi.

Rasio FDR digunakan sebagai rasio untuk mengetahui fungsi intermediari dari sebuah bank, karena dalam perhitungan analisis rasio likuiditas dengan FDR ini dapat diketahui seberapa jauh bank dapat memenuhi permintaan kredit kepada nasabah sebagaimana rumusnya total pembiayaan dibagi dengan total dana pihak ketiga, sehingga bank dapat menimbang dan memenuhi kewajibannya untuk segera memenuhi permintaan nasabah pendanaan yang ingin menarik kembali uangnya yang telah digunakan untuk pembiayaan (Dendawijaya, 2005:116). Rumus perhitungan FDR adalah :

$$
\begin{gathered}
F D R= \\
\frac{\text { Jumlah Pembiayaan }}{\text { Total Dana Pihak Ketiga }} \times 100 \%
\end{gathered}
$$

Menurut Muhammad

(2004:123) penempatan dana pada Bank Indonesia adalah saldo rekening giro bank umum dalam rupiah maupun valuta asing di Bank Indonesia. Penempatan pada Bank Indonesia dibagi menjadi:

a. Giro Wadiah

Giro Wadiah adalahsaldo rekening giro bank syariah baik dalam satuan rupiah maupun mata uang asing yang ditempatkan di Bank Indonesia. 
b. Sertifikat Bank Indonesia Syariah (SBIS)

Sertifikat Bank Indonesia Syariah (SBIS) adalah instrumen yang dikeluarkan oleh Bank Indonesia dalam menjaga stabilitas moneter. Sebelumnya instrumen tersebut bernama Sertifikat Wadi'ah Bank Indonesia (SWBI) dengan akad wadi'ah yang digunakan untuk menyerap over liquidity dalam perbankan syariah, namun penggunaan SWBI dikeluhkan oleh perbankan syariah karena rendahnya return yang diterima dibandingkan dengan SBI bank konvensional.

Melalui PBI 10/11/PBI/2008 Bank Indonesia menerbitkan Sertifikat Bank Indonesia Syariah atau SBIS sebagai pengganti SWBI. Menurut PBI 10/11/PBI/2008, karakeristik SBIS adalah sebagai berikut:

1. Satuan unit sebesar Rp.1.000.000,00.

2. Berjangka waktu satu hingga 12 bulan.

3. Diterbitkan tanpa warkat (scripless).

4. Dapat diagunkan kepada Bank Indonesia.

5. Tidak dapat diperdagangkan di pasar sekunder.

SBIS diterbitkan dengan menggunakan akad ju'alah. Bank Indonesia akan menetapkan dan meberikan imbalan bagi pemegang SBIS yang diterbitkan dengan mekanisme lelang dengan peserta Bank Umum Syariah (BUS) atau Unit Usaha Syariah (UUS).

c. Fasilitas Simpanan Bank Indonesia
Syariah (FASBIS)

Menurut Surat Edaran Bank Indonesia No. 11/8/DPM tahun 2009, FASBIS adalah fasilitas simpanan yang disediakan oleh Bank Indonesia kepada bank untuk menempatkan dananya di Bank Indonesia dalam rangka standing facilities syariah. Berikut ketentuan dalam FASBIS:

1. Pengajuan penawaran kuantitas transaksi FASBIS dari setiap peserta transaksi FASBIS paling kurang Rp1.000.000.000,00 (satu miliar rupiah) dan selebihnya dengan kelipatan Rp100.000.000,00 (seratus juta rupiah).

2. Jangka waktu FASBIS paling lama 14 (empat belas) hari kalender dihitung dari tanggal penyelesaian transaksi sampai dengan tanggal jatuh tempo.

3. FASBIS tidak dapat diperdagangkan, tidak dapat diagunkan dan tidak dapat dicairkan sebelum jatuh tempo.

4. FASBIS menggunakan akad wadi'ah Menurut Boediono (1985:155) inflasi adalah kecenderungan atas peningkatan harga-harga secara luas dan terus menerus. Kenaikan dari satu atau dua komoditas belum dapat disebut dengan inflasi, kecuali apabila kenaikan menyebabkan kenaikan harga pada komoditas lainnya. Sedangkan menurut Mankiw (2005:164) inflasi merupakan kenaikan dalam seluruh tingkat harga. Terkadang kenaikan harga ini 
berlangsung dalam periode yang lama dan terus-menerus. Inflasi merupakan fenomena perekonomian secara makro yang dapat terjadi di manapun.

Inflasi adalah fenomena moneter berkaitan dengan mekanisme pasar yang dapat disebabkan oleh berbagai faktor, antara lain tingkat konsumsi masyarakat yang naik tanpa diimbangi dengan stok yang memadahi, kenaikan jumlah uang yang beredar di masyarakat sehingga dapat memicu naiknya konsumsi atau bahkan semakin menuju kearah spekulasi. Dengan kata lain, inflasi merupakan proses menurunnya nilai mata uang secara terus-menerus. Inflasi adalah rangkaian proses dari suatu peristiwa ekonomi yang terjadi secara luas, bukan tinggi rendahnya tingkat harga. Tingkat harga yang tinggi belum tentu menunjukkan terjadinya inflasi. Inflasi juga digunakan dalam mengartikan peningkatan vang beredar yang terkadang dilihat sebagai penyebab meningkatnya harga. Inflasi dapat digolongkan menjadi empat golongan, yaitu:

1. Inflasi ringan, inflasi ringan terjadi apabila kenaikan harga berada di bawah angka $10 \%$ setahun.

2. Inflasi sedang, inflasi sedang antara 10\%-30\% setahun.

3. Inflasi berat, inflasi berat antara $30 \%$ $100 \%$ setahun.

4. Inflasi hiperinflasi, hiperinflasi adalah inflasi yang tak terkendali terjadi ketika apabila kenaikan harga berada di atas
$100 \%$ setahun.

Menurut para ekonom Islam dalam Karim (2007 : 139), inflasi berdampak buruk bagi perekonomian suatu negara karena

1. Menimbulkan gangguan terhadap fungsi uang yaitu sebagai fungsi tabungan (nilai simpanan), fungsi dari pembayaran di muka, dan fungsi dari unit penghitungan. Orang harus melepaskan diri dari vang dan aset kevangan akibat dari beban inflasi tersebut. Inflasi juga telah mengakibatkan terjadinya inflasi kembali, atau dengan kata lain "self feeding inflation".

2. Melemahkan semangat menabung dan sikap terhadap menabung dari masyarakat (turunnya Marginal Propensity to Save).

3. Meningkatkan kecenderungan untuk berbelanja terutama untuk non prime dan barang-barang mewah (naiknya Marginal Propensity to Consume).

4. Mengarahkan investasi pada hal-hal yang non-produktif yaitu penumpukan kekayaan (hoarding) seperti: tanah, bangunan, logam mulia, mata uang asing dengan mengorbankan investasi ke arah produktif seperti: pertanian, industrial, perdagangan, transportasi, dan lainnya.

Berdasarkan rumusan masalah, kajian teori dan penelitian sebelumnya, hipotesis dapat dirumuskan sebagai berikut :

$\mathrm{H}_{0 a}$ : financing to deposit ratio (FDR), penempatan pada bank 
Muhammad, et al/Jurnal Ekonomi Syariah Teori dan Terapan Vol. 6 No. 4 April 2019: 672-686; PENGARUH FAKTOR INTERNAL DAN EKSTERNAL BANK SYARIAH TERHADAP KEPUTUSAN INVESTASI SURAT BERHARGA BANK SYARIAH

indonesia, dan inflasi secara simultan tidak berpengaruh terhadap keputusan investasi surat berharga Bank Umum Syariah di Indonesia

$\mathrm{H}_{\mathrm{la}}$ : financing to deposit ratio (FDR), penempatan pada bank indonesia, dan inflasisecara simultan berpengaruh terhadap keputusan investasi surat berharga Bank Umum Syariah di Indonesia $\mathrm{H}_{\mathrm{ob}}$ : financing to deposit ratio (FDR), penempatan pada bank indonesia, dan inflasisecara parsial tidak berpengaruh terhadap keputusan investasi surat berharga Bank Umum Syariah di Indonesia $\mathrm{H}_{1 \mathrm{~b}}$ : financing to deposit ratio (FDR), penempatan pada bank indonesia, dan inflasisecara parsial berpengaruh terhadap keputusan investasi surat berharga Bank Umum Syariah di Indonesia

Metode analisis regresi berganda (Least Squares) digunakan untuk mengetahui pengaruh variabel bebas terhadap variabel terikat. Dalam penelitian ini, persamaan model yang digunakan adalah :

$$
\begin{aligned}
& \alpha_{0}+\beta_{1} X_{1}+\beta_{2} X_{2}+\beta_{3} X_{3}+\beta_{4} X_{4}+\mu \\
& \text { dimana, }
\end{aligned}
$$

$Y=$ Investasi Surat BerhargaSyariah

$X_{1}=$ Financing to Deposit Ratio (FDR)

$\mathrm{X}_{2}=$ Penempatan pada Bank Indonesia FASBIS

$\mathrm{X}_{3}=$ Penempatan pada Bank Indonesia SBI

$\mathrm{X}_{4}=$ Inflasi

$\alpha_{0}=$ Intercept (konstanta)

$\beta_{1} \beta_{2} \beta_{3} \beta_{4}=$ Koefisien regresi masing-masing variabel

$\mu=$ Error term

III. METODE PENELITIAN

Pendekatan penelitian ini adalah dengan pendekatan kuantitatif. Berdasarkan dengan Pedoman Penulisan dan Pembimbingan Skripsi Universitas Airlangga Fakultas Ekonomi (2009:14), pendekatan kuantitatif dalam pelaksanaan penelitiannya mengarahkan masalah menjadi suatu hubungan kausalitas, sehingga rumusan masalah yang telah ditetapkam dapat dijelaskan dalam bentuk hubungan antar variabel. Pendekatan ini dipilih berdasarkan masalah yang terdapat dalam penelitian ini, yaitu mencari pengaruh dari Financing to Deposit Ratio (FDR), Penempatan Pada Bank Indonesia, dan Inflasi terhadap keputusan Investasi Surat Berharga Bank Umum Syariah di Indonesia Juni 2014 Desember 2017.

Variabel dalam penelitian ini dipilih untuk membatasi informasi yang tidak berkaitan dengan penelitian. Variabel dalam penelitian sebagai berikut:

1. Variabel Independen (variabel $x$ ) dalam penelitian ini adalah financing to deposit ratio, penempatan pada Bank Indonesia FASBIS, penempatan pada Bank Indonesia SBIS dan Inflasi.

2. Variabel Dependen dalam penelitian ini adalah investasi surat berharga syariah.

Dalam penelitian ini, teknik analisis yang digunakan untuk mengukur pengaruh variabel bebas terhadap 
variabel terikat dan menjawab rumusan masalah serta mendapatkan hasil analisis regresi adalah regresi linier berganda atau OLS (Ordinary Least Square) dengan menggunakan perangkat EViews 9.0. Analisis regresi linier berganda adalah analisis terhadap model regresi yang memiliki lebih dari satu variabel bebas untuk dapat menjelaskan variasi pada variabel terikat berdasarkan pada beberapa asumsi penting dari model regresi linier (OLS). Asumsi-asumsi tersebut ialah model regresi linier dalam parameter, error term $(\mu)$ memiliki distribusi normal, varian tetap (homokedastisitas), tidak ada hubungan antara variabel bebas dan error term, tidak ada korelasi serial antara error, tidak terjadi hubungan antar variabel bebas (multikolinieritas) pada regresi linier berganda.

\section{HASIL DAN PEMBAHASAN}

\section{Uji Simultan}

Berdasarkan uji simultan (F-test) yang, nilai probabilitas F-statistic adalah 0,000000 . Nilai itu lebih kecil dari $a=5 \%$. Hal itu berarti Hla diterima. Berdasarkan uji tersebut, financing to deposit ratio (FDR), penempatan dana pada FASBIS, penempatan dana pada SBIS, dan inflasi secara simultan berpengaruh signifikan terhadap investasi surat berharga syariah pada bank umum syariah di Indonesia.

\section{Uji Parsial}

\section{Pengaruh Financing to Deposit Ratio (FDR)} pada Investasi Surat Berharga

Hasil uji parsial (T-test) dari variabel financing to deposit ratio (FDR) berpengaruh negatif dan signifikan terhadap investasi surat berharga. Hal tersebut menunjukkan bahwa ketika Bank Umum Syariah meningkatkan FDR menyebabkan bank akan mengurangi Investasi pada Surat Berharga Syariah. Hal tersebut sesuai dengan salah satu tujuan manajemen likuiditas dalam Muhamad (2015:166) yaitu untuk meminimalkan dana yang mengendap idle fund. Ketika bank syariah kesulitan dalam menyalurkan dana kepada pembiayaan, maka bank akan memiliki banyak dana yang mengendap idle fund. Menurut Moestadjab (1995: 47), apabila terdapat kesulitan dalam penempatan dana berupa kredit atau pembiayaan, maka penempatan dana pada secondary reserve yang menurut Muhammad (2015:173) berupa instrumen keuangan syariah harus benar-benar diperhatikan dan menguntungkan.

\section{Pengaruh Penempatan dana pada FASBIS} terhadap Investasi Surat Berharga

Berdasarkan hasil uji parsial (T-test) dari variabelpenempatan dana pada FASBIS berpengaruh negatif dan signifikan terhadap investasi surat berharga. Hal tersebut menunjukkan bahwa ketika Bank Umum Syariah meningkatkan penempatan dana pada FASBIS menyebabkan bank akan mengurangi Investasi pada Surat Berharga Syariah. Sebaliknya bila Bank Umum Syariah sedang kelebihan likuiditas dan ingin menempatkan dananya dalam jangka panjang, maka bank akan mengurangi 
Muhammad, et al/Jurnal Ekonomi Syariah Teori dan Terapan Vol. 6 No. 4 April 2019: 672-686; PENGARUH FAKTOR INTERNAL DAN EKSTERNAL BANK SYARIAH TERHADAP KEPUTUSAN INVESTASI SURAT BERHARGA BANK SYARIAH

penempatan dananya pada Fasilitas Simpanan Bank Indonesia Syariah (FASBIS) yang hanya berjangka 14 hari, hal tersebut akan menaikan jumlah penyalurannya kepada surat berharga.

Pengaruh Penempatan dana pada SBIS terhadap Investasi Surat Berharga

Berdasarkan hasil uji parsial (T-test) dari variabelpenempatan dana pada SBIS berpengaruh negatif dan signifikan terhadap investasi surat berharga. Hal tersebut menunjukkan bahwa ketika Bank Umum Syariah sedang kelebihan likuiditas dana dengan jangka pendaanaan waktu 1 sampai 12 bulan, maka bank syariah akan meningkatkan penempatan dana pada SBIS dan menyebabkan bank akan mengurangi Investasi pada Surat Berharga Syariah. Sebaliknya bila Bank Umum Syariah memiliki likuiditas berlebih dengan jangka waktu pendanaan diatas satu tahun, maka bank akan menambah penempatan dananya pada Sertifikat Bank Indonesia Syariah, hal tersebut akan menurunkan jumlah penyalurannya kepada surat berharga, hal tersebut dikarenakan return yang diterima dari penempatan dana pada surat berharga syariah lebih besar dibanding return yang akan diterima dari penempatan SBIS yang berkisar 4,75\%. Selain itu menurut Ismal (2013:209) sekitar 76,4 persen bank syariah memilih menempatkan dananya pada Surat Berharga Syariah Negara (SBSN) yang dianggap lebih profitable dan tradeable ketika bank syariah memerlukan likuiditas.
Pengaruh Inflasi terhadap Investasi Surat Berharga

Berdasarkan hasil uji parsial (T-test) dari variabelinflasi berpengaruh negatif dan signifikan terhadap investasi surat berharga. Hal tersebut menunjukkan bahwa ketika inflasi naik, bank syariah akan mengurangi Investasi pada Surat Berharga Syariah. Sedangkan pada saat inflasi turun, maka bank akan menambah jumlah investasinya. Hasil penelitian ini tidak sesuai dengan penyataan Ismal (2013:162) ketika terjadi guncangan makroekonomi maka akan berdampak pada kenaikan jumlah Investasi Surat Berharga. Namun hasil yang didapatkan tersebut secara teori konvensional diperkuat dengan pernyataan Tandelilin (2010:342) yang menayatakan inflasi merupakan kecenderungan terjadinya peningkatan harga produk-produk secara keseluruhan. Inflasi yang tinggi mengurangi tingkat pendapatan riil yang diperoleh investor dari investasi. Sebaliknya, jika tingkat inflasi suatu negara mengalami penurunan maka hal ini merupakan sinyal yang positif bagi investor seiring dengan turunnya risiko daya beli uang dan risiko penurunan pendapatan riil. Jika dilihat dari segi perusahaan, inflasi dapat meningkatkan biaya faktor produksi. Apabila biaya faktor produksi seperti bahan baku dan lain-lain meningkat, maka akan menurunkan profitabilitas perusahaan sehingga return saham yang dibagikan melalui dividen juga akan semakin sedikit. Dari 
pernyataan Tandelilin tersebut, maka inflasi memiliki pengaruh negatif terhadap investasi. Bahasan dari penelitian ini dapat dikaji lebih lanjut dalam mencari penyebab perbedaan antara 2 pendapat yang terjadi dalam hasil penelitian ini, yaitu pendapat dari Ismal (2013:162) dengan Tandelilin (2010:342).

\section{SIMPULAN}

\section{Kesimpulan}

Berdasarkan hasil penelitian dan juga pembahasan yang telah dilakukan mengenai, maka simpulan yang dapat diambil adalah:

1. Variabel financing to deposit ratio (FDR), penempatan dana pada FASBIS, penempatan dana pada SBIS, dan inflasi secara simultan semua variabel berpengaruh positif signifikan terhadap investasi surat berharga syariah pada bank syariah di Indonesia pada periode Juni 2014 - Desember 2017. pada signifikansi a $5 \%$ dengan probabilitas 0,00000 .

2. Variabel financing to deposit ratio (FDR) berpengaruh negatif dan signifikan terhadap jumlah investasi surat berharga bank syariah di Indonesia periode tahun 2014 - 2017 pada signifikansi a $5 \%$ dengan nilai tstatistik sebesar -16.97444 dan nilai signifikansi 0,0000.

3. Variabel penempatan dana pada FASBIS berpengaruh negatif dan signifikan terhadap jumlah investasi surat berharga bank syariah di Indonesia periode tahun 2014 - 2017 pada signifikansi a $5 \%$ dengan nilai tstatistik sebesar -8.161194 dan nilai signifikansi 0,0000.

4. Variabel penempatan dana pada SBIS berpengaruh negatif dan signifikan terhadap jumlah investasi surat berharga bank syariah di Indonesia periode tahun 2014 - 2017 pada signifikansi a $5 \%$ dengan nilai t-statistik sebesar -2.988315 dan nilai signifikansi 0,0049 .

5. Variabel inflasi berpengaruh negatif dan signifikan terhadap jumlah investasi surat berharga bank syaric 82 i Indonesia periode tahun 2014 - 2017 pada signifikansi a $5 \%$ dengan nilai $t-$ statistik sebesar -5.460758 dan nilai signifikansi 0,0000 .

\section{Saran}

1. Bagi Bank Umum Syariah

Hasil penelitian yang menunjukkan bahwa ketika bank kelebihan likuiditas, maka bank akan menyalurkan pada instrumen surat berharga. Dimana terjadi trade off antara financing to deposit ratio (FDR). Hal tersebut tentunya dapat mengganggu peran bank syariah sebagai lembaga intermediasi yang menyalurkan dana dari pihak surplus kepada pihak defisit. Sehingga diharapkan bank syariah mampu menyalurkan DPK dalam bentuk pembiayaan lebih baik agar tetap menjaga fungsi bank syariah sebagai lembaga intermediasi yang disertai dengan proses manajemen pembiayaan yang lebih baik. 
2. Bagi Peneliti Berikutnya

Dalam penelitian ini penulis menduga variabel financing to deposit ratio (FDR) merupakan variabel intervening antara penempatan dana di Bank Indonesia dan inflasi. Sehingga diharapkan peneliti selanjutnya mampu membuktikan dugaan tersebut dan bisa menambah khazanah keilmuan dalam bidang Manajemen Bank Syariah terutama Manajemen Dana dan Likuiditas Bank Syariah.

\section{DAFTAR PUSTAKA}

Al-Qur'an dan Terjemahannya.

Airlangga, Universtity. 2009. Pedoman Penulisan Pembimbingan dan Ujian Skripsi. Surabaya : Airlangga University Press.

Ajija, Shochrul R dkk. 2011. Cara Cerdas Menguasai EViews. Jakarta : Salemba Empat.

Alma, Buchari \& Donni Juni Priansa. 2009. Manajemen Bisnis Syariah. Bandung : Alfabeta.

Antonio, Muhammad Syafi'i. 2001. Bank Syariah Dari Teori ke Praktik. Jakarta: Gema Insani.

Arifin, Zainul. 2003. Dasar-Dasar Manajemen Bank Syariah. Jakarta: AlvaBet. 2009.

Dasar-Dasar

Manajemen Bank Syariah. Ciputat. Tanggerang: Azkia.

Ascarya, 2008. Akad dan Produk Bank Syariah, Jakarta : PT.Raja Grafindo. Persada.
Boediono. 1985. Teori Pertumbuhan Ekonomi. Yogyakarta : Penerbit BPFE.

2005. Ekonomi Moneter Edisi 3. Yogyakarta.: BPFE.

Dendawijaya, Lukman. 2005. Manajemen Perbankan. Edisi Kedua. Bogor : Ghalia Indonesia

Hasan, Nurul Ichsan. 2014. Pengelolaan Likuiditas Bank Syariah. Al-lqtishad: Journal of Islamic Economics 2014.

Huda, Nurul dan Heykal, Mohamad .2010. Lembaga Kevangan Islam: Tinjauan Teoritis dan. Praktis. Jakarta: Kencana.

Ismal, Rifki. 2010. The management of liquidity risk in Islamic Banks: the case of indonesia, Durham University : Doctoral dissertation. .2013. Islamic Banking in Indonsia: New Perspectives on Monetary and Financial Issues. Singapore: John Wiley.

Kasmir .2012. Analisis Laporan Kevangan.Jakarta: Salemba Empat.

Mankiw, Gregory. 2005. Teori Makroekonomi. Jakarta: Erlangga. Widjajono Moestadjab. $1995 . \quad$ Asset Liability Management (ALMA). Surabaya: BP-IPI

Muhammad. 2005. Manajemen Perbankan Syariah. Yogyakarta: UPP STIM YKPN. . 2006. Bank Syariah Analisis Kekuatan, Peluang, Kelemahan 
Muhammad, et al/Jurnal Ekonomi Syariah Teori dan Terapan Vol. 6 No. 4 April 2019: 672-686; PENGARUH FAKTOR INTERNAL DAN EKSTERNAL BANK SYARIAH TERHADAP KEPUTUSAN INVESTASI SURAT BERHARGA BANK SYARIAH

dan Ancaman. Yogyakarta: EKONISIA

. 2011. Manajemen Bank Syariah. Yogyakarta: UPP STIM YKP . 2015. Manajemen Dana Bank Syariah. Jakarta:PT RajaGrafindo Persada

Muljawan, Dadang. dkk. 2014. Penggunaan Sukuk IILM Sebagai Instrumen Investasi dan Likuiditas Perbankan Syariah.Working Paper 7 Bank Indonesia Desember 2014.

Rivai, Veitzhal dkk. 2012. Principle of Islamic Finance ( Dasar-DasarKeuangan Islam ). Yogyakarta : BPFE.

Soemitra,Andri . 2009. Bank dan Lembaga Kevangan Syariah. Jakarta: Kencana.

Tandelilin, Eduardus. 2010. Portofolio dan Investasi Teori dan Aplikasi. Edisi pertama. Yogyakarta : Kanisius.

Taswan. 2010. Manajemen Perbankan Konsep, Teknik, dan Aplikasi. Edisi. Kedua. Yogyakarta: UPP STIM YKPN.

Umar, Azwar. 2014. Pengaruh Penerbitan Sukuk Negara Sebagai Pembiayaan Defisit Fiskal dan Kondisi Ekonomi Makro Terhadap Perkembangan Perbankan Syariah di Indonesia. Jurnal of Info Artha Sekolah Tinggi Akuntansi Negara (STAN). II. 1-21.

Undang-Undang No.21 tahun 2008 www.academia.edu/25443636/MANAJEM EN_DANA_BANK_SYARIAHdiaksesp ada 25 Februari 2018 www.bi.go.iddiaksespada 25 Februari 2018 www.ojk.go.iddiaksespada 24 Februari 2018

https://www.brisyariah.co.id/files/reports/a nnual_2012.pdfdiaksespada 24 Februari 2018 